\title{
Active Sports Tourism in Slovenia: Preliminary Research
}

\author{
Damjan Pintar \\ Fakulteta za komercialne in poslovne vede, Celje, Slovenia
}

\begin{abstract}
Researches from last years in the Alpine space and countries that develop active tourism, shows that tourist, that are interested into active holidays targeting sport oriented or relaxing holidays with elements of sports, are better consumers, higher on the social scale and live in bigger cities. At the same time this consumers spend their holidays several times a year, on a shorter base. Sport is also starting to be one of the main decision-making factors for majority of tourist in this region. This is proved by constant increase of Active sport holidays or Sport related holidays in development of successful tourist destinations in Europe. Goal of this work is to present preliminary research of potentials for active holidays in part of Slovenian mountain region. The research is made in the sample of tourists that are based in hotels and apartments of Slovenian tourist destination Kranjska Gora in the facilities of Hit Alpinea (HA) company. The habits, plans, consumption and type of accommodation related to active holidays were examined.
\end{abstract}

Keywords: tourist destination, active sports tourism, active lifestyle, Slovenia, HIT Alpinea

JEL classification: L83

\section{Introduction}

Tourist industry which becomes more and more important element of national economies in central European countries and in Alpine region already exists few decades as an important part of economy there is because of globalization, development of communication technologies influenced fast development (Weed, 2006).

In the past tourist product consist of proper accommodation, culinary and animation services which is now only staring point of and tourist product. Nowadays with the use modern communication platforms and knowledgeable tourists sophisticated programs are touching tourists with different names of the programs and brands that representing those (De Knop, 1990; Bell et al., 2011). Sports and other elements of active holidays represents crucial part of destinations, because destinations that offers system of active programs with inclusion of knowhow and at the same time other elements as culture, ethnology, becomes winners at international tourist markets (Huggins, 2013).

Purpose of the paper is to investigate the tourist with active and relaxation aims of their holidays in Kranj, Slovenia. We have chosen this particular region because it is already established active tourism region, with the potential to achieve much more. Goal of the paper is to provide the answer to the following questions: (i) how many tourists that come to Kranjska Gora have active and how many relaxation aim of the holidays; (ii) what are the differences among active and relaxation type of tourists according to their demographic characteristics, (iii) what are the differences among 
active and relaxation type of tourists according to vacation habits; and (iv) what are the differences according to the used sources of information.

\section{Active sports tourism}

Active sports tourism is new opportunity for development of tourist companies, clubs, local communities and individual entrepreneurs, because synergetic cooperation of different mentioned stakeholders brings benefits to all and in particular tourist destination as whole.

Subjects of legal law (hotel companies, accommodation facilities, organizers of professional sports services) with their programs of active holidays develops and widen the spectrum of activities linked with classic tourist approach, targeting new consumers and target groups, and overcome seasonal meaning of tourism.

Public sector with facilities and services they provide for inhabitants at the market, get new resources and founds, which could is in the time of decreasing of public money represents one of the pillars of financing.

Sports clubs, associations and individuals could similar to the public sector decreasing dependence on public money and provide optimal conditions for their programs.

Active sport tourism products are positioning tourist destinations higher on the scale and provide better marketing and higher incomes in tourism.

Concerning many different forms of sport in tourist products we can present three basic aspects of sport tourism (Gibson 1998). First is defined as active participation of individual in sport activities during holidays. We know this as sports recreation products, prophylactic programs with sport products during holidays, use of sport and kinesiology at the second stage of rehabilitation out of hospital in tourist and spa resorts, or as a training and preparation camps of individuals ant sport teams (Berčič, Pintar et. al. 2010). Second aspect represents sport events as a part of active holidays, where travel of individual is part of the process. Sports competitions as Olympic Games, World and continental cups and championships or other interesting events connected with sports topics on seminars, congresses and meeting of professionals and public representing this aspect as well. Third aspect represents travel to destinations that are connected with sports, sport events, famous athletes, events or sporting organizations.

In this research we will analyze first aspect of sport offers in the tourist products. Central part of Europe, with Southern Alps, western Pannonian flat and Nord-west Mediterranean is ideal, but not developed and recognized destination yet. Destination could already offer high quality services of accommodation, organic food, but also active programs, because of some important comparative advantage that the region could offer. The cultural common space of Southern Alps, Pannonian flat and Mediterranean space, has traditional highly developed and well managed sport organizations and clubs, cultural programs and heritage, but they are not sufficiently included into the complex advanced tourist programs.

\section{Methodology}

Slovenia is one of CE destinations that have ideal possibilities for developing sport tourism. Tradition of sports clubs, international sports events, and active holidays such as skiing biking, hiking, canoeing and kayaking, sailing... is solid base for sports tourism in different forms. There is several tourist resorts, that are developing sports tourism and would like to offer active packages in Slovenia. Kranjska Gora because of its natural predisposition, infrastructure, organization of international sporting 
events and active holidays for families represents typical micro destination of active sport tourism in the country.

There are many tourist companies, that are organizing sport related programs, but Hit Alpinea represents the biggest one, with more than 1500 beds in hotels and apartments including wellness and spa areas. HiT Alpinea started to prepare new strategy for the period until 2020, and it is ideal opportunity to position active sport tourism as one of the most important fields in their portfolio.

Currently there is a mixture of guests in selected hotels and lack of systematic approach in marketing and in servicing of those guests. They have standard offers, and majority of services is not developed or used which means many possibilities for development, from sport recreational programs for tourist of different age groups, to active involvement in creation and organization of sport related events.

This preliminary survey is test of the pre-season guests, that are visiting HA resorts, and we wanted to learn about their habits, motives, social status, place of residence and other related and important elements for active sport tourism.

\section{Research results}

Table 1 represents the respondents' main aim of the vacation. Most of the respondents $(58,3 \%$ ) aim to have active holidays (sport holidays and relaxation in the nature). Still, there is large number of those who aim to have relaxation holidays, but with some elements of sports $(41,7 \%)$.

Table 1

Respondents' main aim of the vacation

\begin{tabular}{lcc}
\hline Main aim of the vacation & $\mathrm{n}$ & $\%$ \\
\hline $\begin{array}{l}\text { Active holidays - main aim si sport holidays } \\
\text { and relaxation in the nature }\end{array}$ & 21 & 58,3 \\
$\begin{array}{l}\text { Relaxation holidays - main aim is relaxation } \\
\text { with some elements of sports }\end{array}$ & 15 & 41,7 \\
\begin{tabular}{l} 
Total \\
\hline
\end{tabular} & 36 & 100 \\
\hline
\end{tabular}

Source: Author survey

Table 2 represents characteristics of the respondents according to active and relaxation aim of the vacation. Male respondents aim to the greater extent relaxation holidays $(44,4 \%)$, while female respondents aim to the greater extent active holidays $(55,6 \%)$. Still, this difference is not statistically significant ( $p$ value $=0,738$ ). 
Table 2

Characteristics of the respondents according to active and relaxation aim of the vacation

\begin{tabular}{|c|c|c|c|c|c|c|}
\hline & $\mathbf{n}$ & $\%$ & Cumulative \% & \% Active & \% Relaxation & Chi-square ( $p$-value) \\
\hline \multicolumn{7}{|c|}{ Gender } \\
\hline Male & 18 & 50,0 & 50,0 & 44,4 & 55,6 & 0,111 \\
\hline Female & 18 & 50,0 & 100,0 & 55,6 & 44,4 & $(0,738)$ \\
\hline Total & 36 & 100,0 & & & & \\
\hline \multicolumn{7}{|c|}{ Age } \\
\hline 25 to 29 years & 4 & 11,1 & 11,1 & $50,0 \%$ & $50,0 \%$ & 12,842 \\
\hline 30 to 39 years & 9 & 25,0 & 36,1 & $55,6 \%$ & $44,4 \%$ & $\left(0,012^{* *}\right)$ \\
\hline 40 to 49 years & 13 & 36,1 & 72,2 & $84,6 \%$ & $15,4 \%$ & \\
\hline 50 to 59 years & 7 & 19,4 & 91,7 & $14,3 \%$ & $85,7 \%$ & \\
\hline 60 years and more & 3 & 8,3 & 100,0 & & $100,0 \%$ & \\
\hline Total & 36 & 100,0 & & & & \\
\hline \multicolumn{7}{|c|}{ Country of residence } \\
\hline Checz Republic & 1 & 2,8 & 2,8 & $100,0 \%$ & & 10,074 \\
\hline India & 3 & 8,3 & 11,1 & & $100,0 \%$ & $\left(0,073^{*}\right)$ \\
\hline Italy & 1 & 2,8 & 13,9 & $100,0 \%$ & & \\
\hline Polland & 3 & 8,3 & 22,2 & $100,0 \%$ & & \\
\hline Slovenia & 26 & 72,2 & 94,4 & $46,2 \%$ & $53,8 \%$ & \\
\hline United Kingdom & 2 & 5,6 & 100,0 & $100,0 \%$ & & \\
\hline Total & 36 & 100,0 & & & & \\
\hline \multicolumn{7}{|c|}{ Urban / rural areas } \\
\hline Capital city & 10 & 27,8 & 27,8 & $50,0 \%$ & $50,0 \%$ & 2,898 \\
\hline Smaller town & 14 & 38,9 & 66,7 & $50,0 \%$ & $50,0 \%$ & $(0,408)$ \\
\hline Suburb & 4 & 11,1 & 77,8 & $25,0 \%$ & $75,0 \%$ & \\
\hline Village & 8 & 22,2 & 100,0 & $75,0 \%$ & $25,0 \%$ & \\
\hline Total & 36 & 100,0 & & & & \\
\hline
\end{tabular}

Note: ** statistically significant at $5 \% ;{ }^{*}$ statistically significant at $10 \%$

Source: Author survey

Table 3 represents respondent's vacation habits according to active and relaxation aim of the vacation. Large amount of respondents, used short holidays ( up to 3 days) $(58,3 \%)$ and $(41,7 \%)$ selected longer holidays. While $(47,6 \%)$ from those on shorter holiday selected active elements, majority $(52,4 \%)$ selected relaxation as primary activity. Still, this difference is not statistically significant $(\mathrm{p}-$ value $=0,738)$. Those who selected longer vacation (60\%) did active holiday as primer activity, and (40\%)relax while staying longer.

Majority of tourist spending belonging to the group who spends per day 30-50 Eur (47\%),from 50 - 70 Eur (25\%), from 70 - 100 Eur (16,7\%) and minority represents those who spend a lot more than 100 Eur $(8,3 \%)$ and less than 30 Eur $(2,8 \%)$

Tourists that visited KG in spring 2015 usually spends their holidays out of the main seasons all around the year $(44,4 \%)$ and $(33,3 \%)$ spends their holidays out of the main season in summer time. Minority spends their holiday in main seasons $(2,8 \%)$ in summer, $(11,1 \%)$ in the winter and $(8,3 \%)$ in the main seasons throughout the year. Tourists who booked their vacations thru travel agents represents (41\%), (33,3\%)made 
bookings via new media and (25\%) booked directly, based on previous experience or recommendation. Majority booked 4 star hotels $(63,9 \%)$ and $(22,2 \%)$ booked 3 star hotels, while only (13,9\%) booked apartments.

Table 3

Respondents vacation habits according to active and relaxation aim of the vacation

\begin{tabular}{|c|c|c|c|c|c|c|}
\hline & $\mathbf{n}$ & $\%$ & Cumulative \% & \% Active & \% Relaxation & $\begin{array}{l}\text { Chi-square } \\
\text { (p-value) }\end{array}$ \\
\hline \multicolumn{7}{|c|}{ Length of the stay } \\
\hline $\begin{array}{l}\text { Shorter vacations (up to } 3 \\
\text { days) }\end{array}$ & 21 & 58,3 & 58,3 & $47,6 \%$ & $52,4 \%$ & $\begin{array}{r}0,538 \\
(0,463)\end{array}$ \\
\hline $\begin{array}{l}\text { Longer vacations (from } 3 \text { to } 7 \\
\text { days or more) }\end{array}$ & 15 & 41,7 & 100,0 & $60,0 \%$ & $40,0 \%$ & \\
\hline Total & 36 & 100,0 & & & & \\
\hline \multicolumn{7}{|c|}{ Estimated spending per adult per day (incl accommodation, activities, restaurant, shopping) } \\
\hline from 30 EUR & 1 & 2,8 & 2,8 & & $100,0 \%$ & 7,887 \\
\hline From 30 to 50 EUR & 17 & 47,2 & 50,0 & $58,8 \%$ & $41,2 \%$ & $\left(0,096^{*}\right)$ \\
\hline From 50 to 70 EUR & 9 & 25,0 & 75,0 & $77,8 \%$ & $22,2 \%$ & \\
\hline From 70 to 100 EUR & 6 & 16,7 & 91,7 & $33,3 \%$ & $66,7 \%$ & \\
\hline More than 100 EUR & 3 & 8,3 & 100,0 & & $100,0 \%$ & \\
\hline Total & 36 & 100,0 & & & & \\
\hline \multicolumn{7}{|c|}{ Usual time for holidays } \\
\hline $\begin{array}{l}\text { In main seasons (school } \\
\text { holidays, school holidays } \\
\text {...) in summer }\end{array}$ & 1 & 2,8 & 2,8 & & $100,0 \%$ & $\begin{array}{r}3,232 \\
(0,520)\end{array}$ \\
\hline $\begin{array}{l}\text { Out of main seasons in the } \\
\text { winter }\end{array}$ & 4 & 11,1 & 13,9 & $25,0 \%$ & $75,0 \%$ & \\
\hline $\begin{array}{l}\text { Out of the main seasons in } \\
\text { the summer }\end{array}$ & 12 & 33,3 & 47,2 & $50,0 \%$ & $50,0 \%$ & \\
\hline $\begin{array}{l}\text { In the main seasons all } \\
\text { around the year }\end{array}$ & 3 & 8,3 & 55,6 & $66,7 \%$ & $33,3 \%$ & \\
\hline $\begin{array}{l}\text { Out of the main seasons all } \\
\text { around the year }\end{array}$ & 16 & 44,4 & 100,0 & $62,5 \%$ & $37,5 \%$ & \\
\hline Total & 36 & 100,0 & & & & \\
\hline \multicolumn{7}{|l|}{ Way of booking } \\
\hline $\begin{array}{l}\text { Directly on my own based } \\
\text { on experience or } \\
\text { recommendation of my } \\
\text { friends }\end{array}$ & 9 & 25,0 & 25,0 & $44,4 \%$ & $55,6 \%$ & $\begin{array}{r}2,006 \\
(0,367)\end{array}$ \\
\hline $\begin{array}{l}\text { Over the travel agencies or } \\
\text { tour operators }\end{array}$ & 15 & 41,7 & 66,7 & $66,7 \%$ & $33,3 \%$ & \\
\hline Over the web & 12 & 33,3 & 100,0 & $41,7 \%$ & $58,3 \%$ & \\
\hline Total & 36 & 100,0 & & & & \\
\hline \multicolumn{7}{|l|}{ Usual kind of accommodation } \\
\hline Hotel $3^{*}$ & 8 & 22,2 & 22,2 & $62,5 \%$ & $37,5 \%$ & 2,588 \\
\hline Hotel $4^{*}$ & 23 & 63,9 & 86,1 & $43,5 \%$ & $56,5 \%$ & $(0,274)$ \\
\hline Apartments & 5 & 13,9 & 100,0 & $80,0 \%$ & $20,0 \%$ & \\
\hline Total & 36 & 100,0 & & & & \\
\hline
\end{tabular}

Note: * statistically significant at $10 \%$

Source: Author survey 
Table 4 presents sources of information about the resort according to active and relaxation aim of the vacation. Majority of those who used relaxation holidays $(66,7 \%)$ got information about holidays on the web, and $(63,6 \%)$ from those that spends their holidays active, got the information from their friend or relatives, while decision based on information from media represents only $(2,5 \%)$.

Table 4

Sources of information about the resort according to active and relaxation aim of the vacation (among those who already knew the resort, the split between active and relaxation holidays was even)

\begin{tabular}{lrrrr}
\hline $\begin{array}{l}\text { Source of information about the } \\
\text { resort }\end{array}$ & $\mathbf{n}$ & \% of total & \% Active & \% Relaxation \\
\hline I knew this resort & 20 & 55,6 & 50 & 50 \\
On the web & 3 & 8,3 & 33,3 & 66,7 \\
\hline From friends or relatives & 11 & 30,6 & 63,6 & 36,4 \\
\hline From media & 1 & 2,8 & 0 & 100 \\
From books or tourist guides & 2 & 5,6 & 50 & 50 \\
Others please write: & 4 & 11,1 & 50 & 50 \\
\hline
\end{tabular}

Source: Author survey

Table 5 presents company at the holidays and previous visits according to active and relaxation aim of the vacation. More than half of them $(52,8 \%)$ arrived with partner and $(52,6 \%)$ of this group used active holidays, while $(22,2 \%)$ arrived with family and relatives and $(62,5 \%)$ of this group spend their holiday mainly relaxing, while $(63,6 \%)$ of active tourists visited HA resorts for the first time and $(52 \%)$ of those that spend relaxing holydays visited HA resorts even before.

Table 5

Company at the holidays and previous visits according to active and relaxation aim of the vacation

\begin{tabular}{|c|c|c|c|c|c|c|}
\hline & $\mathbf{n}$ & $\%$ & Cumulative \% & \% Active & \% Relaxation & $\begin{array}{l}\text { Chi-square } \\
\text { (p-value) }\end{array}$ \\
\hline \multicolumn{7}{|c|}{ Company at the holidays } \\
\hline Here I am alone & 3 & 8,3 & 8,3 & $33,3 \%$ & $66,7 \%$ & 5,670 \\
\hline Partner & 19 & 52,8 & 61,1 & $52,6 \%$ & $47,4 \%$ & $(0,340)$ \\
\hline Family or relatives & 8 & 22,2 & 83,3 & $37,5 \%$ & $62,5 \%$ & \\
\hline Friends & 1 & 2,8 & 86,1 & $100,0 \%$ & & \\
\hline $\begin{array}{l}\text { Colleagues from my } \\
\text { office }\end{array}$ & 3 & 8,3 & 94,4 & $100,0 \%$ & & \\
\hline Other & 1 & 2,8 & 97,2 & $100,0 \%$ & & \\
\hline No answer & 1 & 2,8 & 100,0 & $33,3 \%$ & $66,7 \%$ & \\
\hline Total & 36 & 100,0 & & & & \\
\hline \multicolumn{7}{|l|}{ Previous visits } \\
\hline Here I am the first time & 11 & 30,6 & 30,6 & $63,6 \%$ & $36,4 \%$ & $\begin{array}{r}0,749 \\
(0,387)\end{array}$ \\
\hline $\begin{array}{l}\text { I spent holidays here } \\
\text { several times }\end{array}$ & 25 & 69,4 & 100,0 & $48,0 \%$ & $52,0 \%$ & \\
\hline Total & 36 & 100,0 & & & & \\
\hline
\end{tabular}

Source: Author survey 


\section{Conclusions}

Tourist destinations around the world are organizing more and more sport tourist related events and holidays with main objective to earn more. Event Sport Tourism represents travel where tourists attend the sporting events (Turco et al., 2002). Main motivation is expected economic impact generated by spending of tourists that are visiting those events (Gratton et al., 2000). Incomes of tourists represent one of the most important factors for certain destinations. This leads to the categorization of the tourists regarding spending that they are willing to spend for the travel. Similar situation is, when observing active sport tourists. Research results revealed that majority of the tourists that visited HA resorts in Kranjska Gora out of the main seasons spend between 30 and 100 Eur per day. Selected group is spending their holiday out of main seasons, which is an important indicator for further activities in marketing regarding selected target groups. Majority of those who spend active holidays booked their holiday via travel agents $(41 \%)$ or via new media $(33,3 \%)$, and only (25\%) booked directly which indicates a big potential for direct marketing and sales. Majority of them spends their holidays in hotels. HA resorts are already known as relaxing destination, but have limited number of active tourists that are returning to destination, which indicated possible change for further marketing and activation strategy. Research limitation were small sample, limited period of the research( May and June 2015) and location which was only HA resorts in Kranjska Gora, Slovenia. Further research will be conducted continuously 4 times a year, and sample will be higher. The research will be a part of marketing plane, and findings will be used as marketing tool for the company.

\section{References}

1. Bell, H., Gibson, H. (2011), "Sport and tourism: globalization, mobility and identity", Annals of Leisure Research, Vol. 14 No. 1, pp. 104-105.

2. Berčič, H., Sila, B., Valek, N. S., Pintar, D., Mihalič, T., Juvan, E. (2010), "Šport v turizmu" [Sports in Tourism], Fakulteta za šport, Ljubljana, Slovenija.

3. De Knop, P. (1990), "Sport for all and active tourism", World Leisure \& Recreation, Vol. 32 No. 3, pp. 30-36.

4. Gibson, H.J. (1998), "Sport Tourism: A Critical Analysis of Research", Sport Management Review, Vol. 1 No. 1, pp. 45-76.

5. Gratton, C., Dobson, N., Shibli, S. (2000), "The Economic Importance of Major Sports Events: A Case Study of Six Events", Managing Leisure, Vol. 5 No. 12, pp. 17-28.

6. Huggins, M. (2013), "Sport, tourism and history: current historiography and future prospects", Journal of Tourism History, Vol. 5 No. 2, pp. 107-130.

7. Turco, D.M.; Riley, R.W., Swart, K. (2002), "Sport tourism". Warrington: Fitness Information Technology, Inc.

8. Weed, M. (2006), "Sports Tourism Research 2000-2004: A Systematic Review of Knowledge and a Meta-Evaluation of Methods", Journal of Sport and Tourism, Vol. 11 No.1, pp.5-30.

\section{About the author}

Damjan Pintar has postgraduate degree in sports management (MEMOS) and Master in Sport Organization Management from University Claude Bernerd Lyon 1. Half of his 28 years of professional career, he spent managing tourist company Unitur as marketing and executive director, and half in the management of national Olympic committee of Slovenia. Currently he acts as international consultant at the field of Sports and Tourism in Slovenia and abroad. He is IOC - Olympic Solidarity consultant, member of assembly of Slovenian chamber of Economy and industry and as vice president of European mountain resorts association. As an invited lecturer, he participated in numerous sports marketing seminars and practically developed marketing in several countries around the globe. Damjan Pintar can be contacted at info@sportour.biz 